\title{
Contribution to carrier detection and genetic counselling in X linked retinoschisis
}

\author{
J Kaplan, A Pelet, H Hentati, M Jeanpierre, M L Briard, H Journel, A Munnich, J L Dufier
}

\begin{abstract}
$\mathrm{X}$ linked retinoschisis (RS) is a vitreoretinal disease resulting from microcystic degeneration of the macula associated with peripheral lesions. The disease gene has already been assigned to the distal short arm of the X chromosome (Xp22.2) by linkage studies. In order to contribute both to a better localisation of the RS locus and to genetic counselling in RS families, we have carried out a clinical and genetic analysis in seven pedigrees. We show, first, that in contrast with previous reports, heterozygote carriers frequently express the disease, and display peripheral retinal alterations similar to those found in affected males. Second, while distal markers DXS16, DXS207, and DXS43 are closely linked to the disease locus, a high level of recombination events was found with centromeric markers, namely DXS274, DXS41, and DXS164. These findings must be taken into account for both carrier detection and prenatal diagnosis in $\mathrm{X}$ linked RS.
\end{abstract}

$\mathrm{X}$ linked retinoschisis (RS) is a vitreoretinal disease owing to a microcystic degeneration of the macula. This disorder causes intraretinal splitting (schisis) and peripheral lesions, resulting in the detachment of the retina, with vitreous disturbances. ${ }^{1}$ RS causes a static or slowly progressive impairment of vision usually

Unité de Recherches sur les Handicaps Génétiques de l'Enfant, INSERM U12, Hôpital des Enfants Malades, Paris, France.

J Kaplan, A Pelet, H Hentati, M L Briard, A Munnich

INSERM U129, Centre Hospitalier Universitaire de Cochin, Paris, France.

M Jeanpierre

Centre Hospitalier Régional Prosper Chubert, Vannes, France.

H Journel

Consultation d'Ophthalmologie, Hôpital Laënnec, Paris, France.

J L Dufier

Correspondence to J Kaplan.

Received for publication 27 July 1990

Revised version accepted for publication 30 November 1990. discovered during the first decade, sometimes earlier and sometimes much later, depending on the size and location of the lesions. When the schisis is limited to the peripheral retina, reasonably good central vision can be conserved for several decades. When it is located within the macula, impairment of vision is severe and major evidence of progression of the disease is the observation of an increase in the size of the retinoschisis bulla. ${ }^{2}$ While female carriers never have any macular alterations, we have observed that they often display more or less severe peripheral lesions. It is of the highest importance to look for these peripheral anomalies in females belonging to an $\mathrm{X}$ linked retinoschisis family, since these alterations indicate carrier status and must be taken into account in genetic counselling according to the Bayesian method. ${ }^{3}$

In order to contribute both to localisation of the RS locus and to carrier detection in RS families, we have analysed seven pedigrees using polymorphic DNA markers linked to the disease gene on the distal short arm of the X chromosome (Xp22.2). ${ }^{4}$

\section{Patients and methods}

Seven unrelated families were studied, including 22 affected males, 17 obligate carriers, 12 possible carriers, and 19 healthy boys. A total of 22 members belonging to six families underwent careful ophthalmological examination for RS by the same ophthalmologist (15 affected males, five obligate carriers, two possible carriers). For the other seven affected males and for most healthy boys, written ophthalmological reports were required.

Blood samples were obtained from 74 subjects from the seven families studied ( 20 affected males, 17 obligate carriers, 11 possible carriers, 19 healthy males, and seven husbands and wives), corresponding to 57 meiotic events.

For restriction fragment length polymorphism (RFLP) analysis, DNA was extracted from lymphocyte pellets by cell lysis, proteinase $\mathrm{K}$ digestion, phenol/chloroform extraction, ethanol precipitation, and Tris-EDTA resuspension. ${ }^{5}$ DNA $(5 \mu \mathrm{g})$ was cleaved with the restriction enzymes $B g l \mathrm{II}, X b a \mathrm{I}$, PvuII, MspI, PstI, TaqI, and BamHI under appropriate buffer and temperature conditions according to 


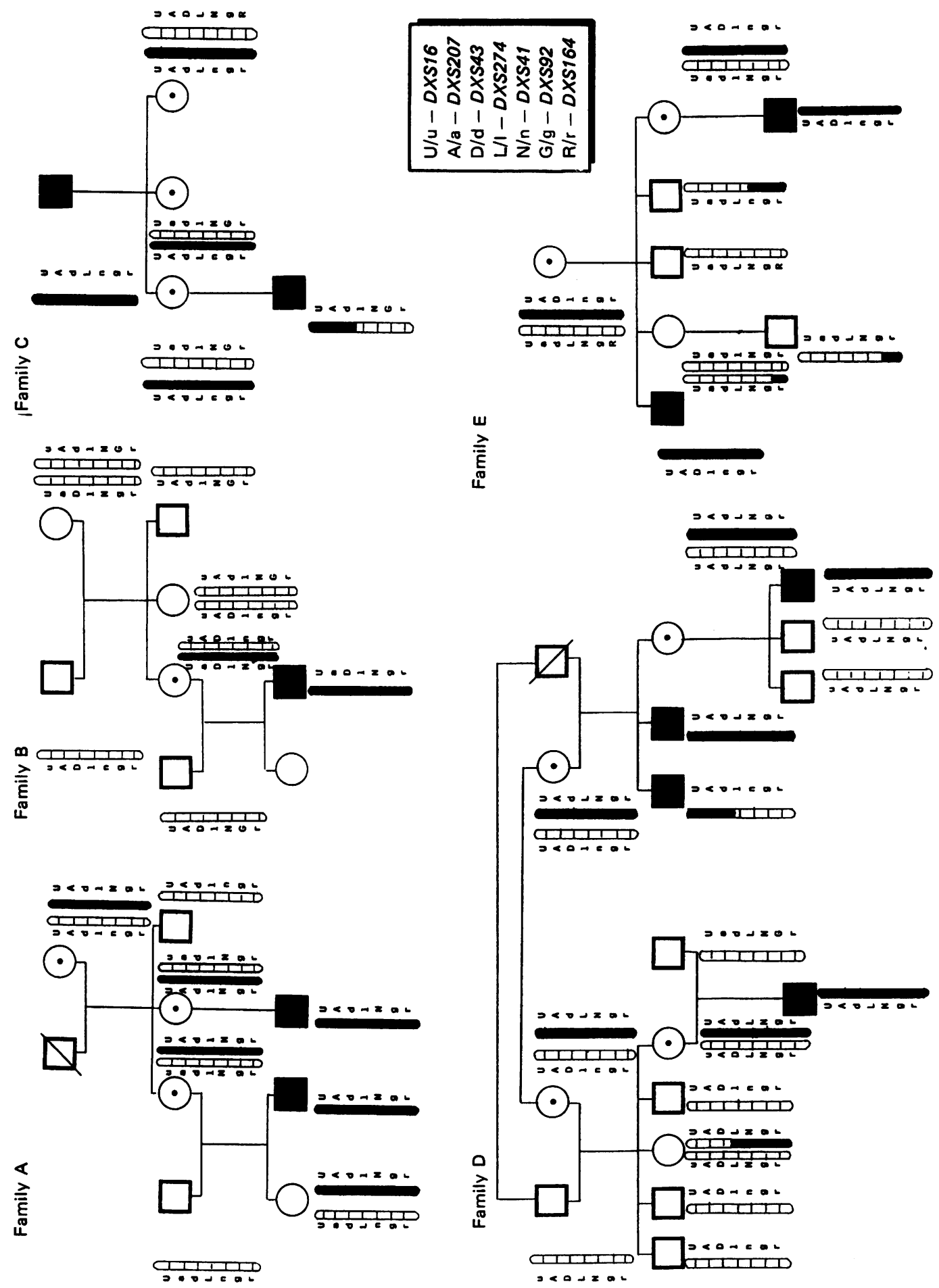




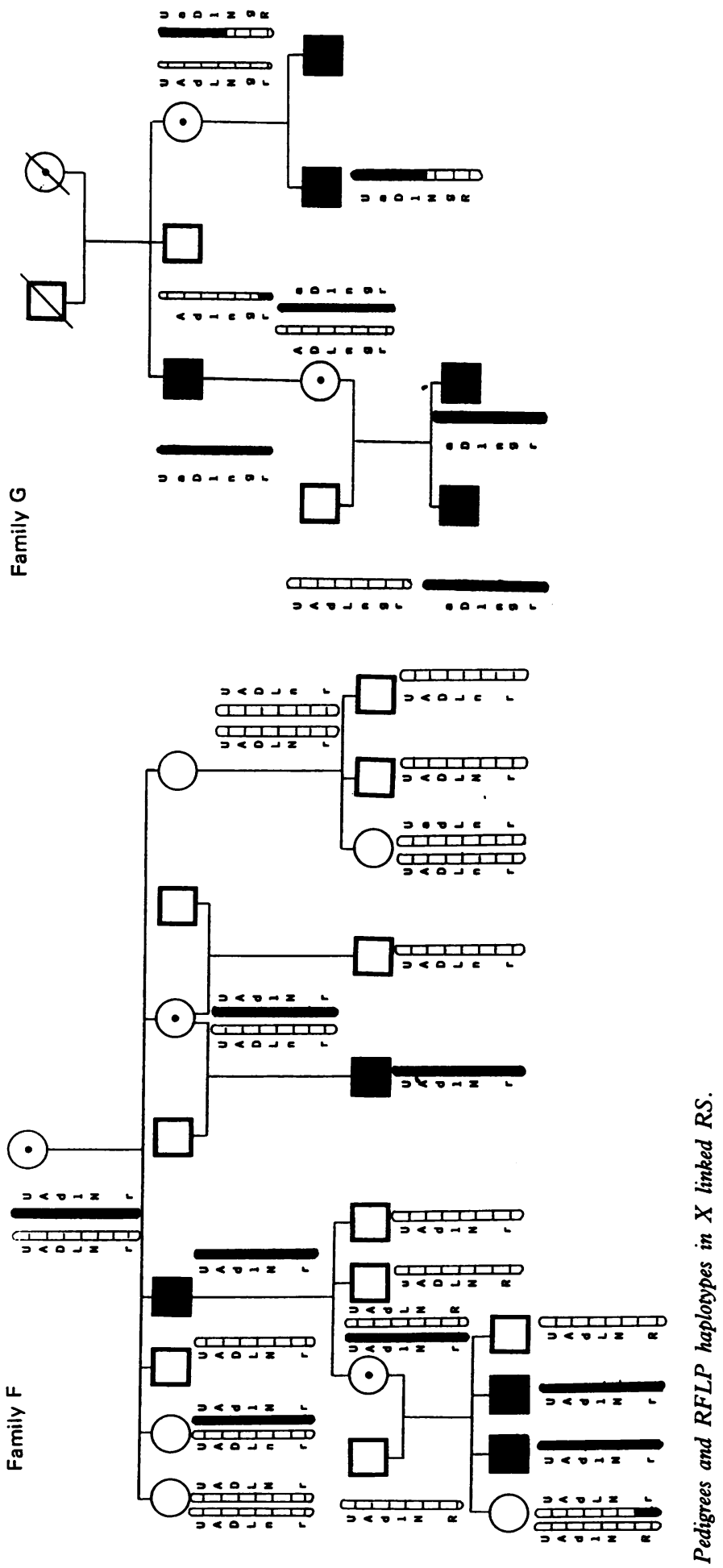


Table $1 X$ chromosome markers used.

\begin{tabular}{|c|c|c|c|c|c|c|}
\hline \multirow[b]{2}{*}{ Locus } & \multirow[b]{2}{*}{ Probe } & \multirow[b]{2}{*}{ Location } & \multirow[b]{2}{*}{ Enzyme } & \multicolumn{2}{|c|}{ Polymorphism } & \multirow[b]{2}{*}{ Reference } \\
\hline & & & & Length (kb) & Frequency & \\
\hline $\begin{array}{l}D X S 16 \\
D X S 207 \\
D X S 43 \\
D X S 274 \\
D X S 41 \\
D X S 92 \\
D X S 164\end{array}$ & $\begin{array}{l}\text { pXUT23 } \\
\text { pPA4B } \\
\text { pD 2 } \\
\text { CRI-L1391 } \\
\text { p99.6 } \\
\text { pXG-16 } \\
\text { pERT87-15 }\end{array}$ & $\begin{array}{l}\text { Xp22.3-p22.2 } \\
\text { Xp22 } \\
\text { Xp22.2 } \\
\text { Xp22.2-p22.1 } \\
\text { Xp22.1 } \\
\text { Xp22.1 } \\
\text { Xp21.2 }\end{array}$ & $\begin{array}{l}\text { BglII } \\
\text { XbaI } \\
\text { PvuII } \\
\text { MspI } \\
\text { PstI } \\
\text { TaqI } \\
\text { BamHI }\end{array}$ & $\begin{array}{l}17.5 / 12.5 \\
12 / 9.5,2.5 \\
6.6 / 6.0 \\
10.5 / 8.6 \\
22 / 13 \\
3.8 / 7.1,3.5 \\
9.4 / 7.1,2.3\end{array}$ & $\begin{array}{l}0.84 / 0.16 \\
0.52 / 0.48 \\
0.29 / 0.71 \\
? \\
0.71 / 0.29 \\
0.50 / 0.40 / 0.10 \\
0.38 / 0.62\end{array}$ & $\begin{array}{l}\text { Bakker et al, } 1985 \\
\text { Ahrens and Kruse, } 1986 \\
\text { Aldridge et al, } 1984 \\
\text { Donis-Keller et al, } 1987 \\
\text { Aldridge et al, } 1984 \\
\text { Sefiani et al, } 1987 \\
\text { Monaco et al, } 1987\end{array}$ \\
\hline
\end{tabular}

the manufacturer's recommendations. The fragments were separated by horizontal gel electrophoresis in Tris-acetate EDTA buffer and transferred onto a nylon membrane (Zetabind, Flo Cuno) using the method of Southern. ${ }^{6}$ Probes were radiolabelled by nick translation to a high specific activity with ${ }^{32} \mathrm{P}$-dCTP (Amersham). ${ }^{7}$ After hybridisation, the filters were washed and exposed to KODAK X/OMAT films with intensifying screens. The probes and some of their relevant characteristics are listed in table 1. Linkage analysis was carried out using the LINKAGE program $^{8}$ version $4 \cdot 8$ on an IBM PC AT.

\section{Results}

Among the five obligate carriers examined, none had macular alterations but four had peripheral lesions. These peripheral lesions of the retina ranged from mild greyish-white spots or dendrite-like areas to a more severe 'palisade' aspect, with possible retinal breaks, corresponding to aberrant zones of underdeveloped capillaries. One obligate carrier also displayed a true peripheral schisis in the lower temporal part of her retina, which required laser photocoagulation. Two additional obligate carriers required cryocoagulation in childhood for peripheral lesions of the retina but no information regarding these lesions could be obtained. Of the two possible carriers, one had dendrite-like alterations in the peripheral retina with a true unilateral schisis in the lower temporal periphery.

Genetics studies were carried out with seven polymorphic probes on the distal short arm of the $\mathrm{X}$ chromosome and informative meiotic events were obtained for all probes but one (DXS92). Strong evidence of linkage to the RS locus was found with three flanking markers, namely DXS207, DXS43, and $D X S 274(\hat{\mathrm{Z}}>3)$. Interestingly, no recombination events were observed with the three polymorphic markers distal to the disease locus (DXS43,DXS207, and $D X S 16$ ). In contrast, five recombination events were found with three proximal markers, namely DXS274, DXS41, and DXS164. The segregation of seven polymorphic markers in our families is shown in the figure and table 2 gives the results of the two point linkage study in these pedigrees.

Finally, the present data suggest that the closest marker centromeric to the disease locus is not $D X S 41$, as previously reported, ${ }^{9-11}$ but rather $D X S 274$ $(\theta=0.08$ and 0.18 for $D X S 274$ and $D X S 41$ respectively, at $\hat{Z}=3.28$ and $1 \cdot 16$ respectively) (table 2 ). It appears therefore that $D X S 43$ and $D X S 274$ are the closest flanking markers in this disease and are at present the most suitable probes for both carrier detection and prenatal diagnosis in RS.

\section{Discussion}

$\mathrm{X}$ linked RS is not an easy disease to diagnose and the difficulty in recognising this condition might possibly account for the longstanding debate regarding the incidence of the disease gene. When schisis is present the diagnosis is certain, but RS can be misdiagnosed when no schisis is observed. It is therefore of primary importance to be aware of all ophthalmological features of the disease. Indeed, RS involves both macular and peripheral lesions of the retina, as previously described by many authors. ${ }^{12-14}$ Microcystic degeneration of the macula is a consistent feature of $\mathrm{X}$ linked RS: its typical angiographic

Table 2 Lod scores between RS and six polymorphic DNA markers using linkage.

\begin{tabular}{|c|c|c|c|c|c|c|c|c|}
\hline & 0.00 & 0.05 & $0 \cdot 10$ & $0 \cdot 20$ & 0.30 & 0.40 & $Z_{\max }$ & $\theta \max$ \\
\hline $\begin{array}{l}D X S 16 \\
D X S 207 \\
D X S 43 \\
D X S 274 \\
D X S 41 \\
D X S 164\end{array}$ & $\begin{array}{c}2 \cdot 42 \\
4 \cdot 17 \\
5 \cdot 91 \\
- \\
- \\
-\end{array}$ & $\begin{array}{c}2.22 \\
3.76 \\
5.33 \\
3 \cdot 19 \\
0.08 \\
-5.6\end{array}$ & $\begin{array}{c}2.01 \\
3.34 \\
4.73 \\
3.26 \\
0.86 \\
-0 \cdot 1\end{array}$ & $\begin{array}{l}1.56 \\
2.47 \\
3.46 \\
2.73 \\
1.15 \\
0.19\end{array}$ & $\begin{array}{l}1.09 \\
1.57 \\
2.14 \\
1.83 \\
0.87 \\
0.24\end{array}$ & $\begin{array}{l}0.57 \\
0.71 \\
0.85 \\
0.80 \\
0.39 \\
0.16\end{array}$ & $\begin{array}{l}2.42 \\
4.17 \\
5.91 \\
3.28 \\
1.16 \\
0.24\end{array}$ & $\begin{array}{l}0.00 \\
0.00 \\
0.00 \\
0.08 \\
0.18 \\
0.28\end{array}$ \\
\hline
\end{tabular}


expression is the so-called 'spoke-wheel' aspect of the macula. ${ }^{15}$ The peripheral lesions, present in about $50 \%$ of male patients, involve silver-grey, glistening, spotty areas scattered over the retina. In addition, perivascular grey cuffs with veils in the vitreous and greyish-white spots suggestive of a healed chorioretinitis are frequently observed. Vitreous haemorrhage and anterior or posterior vitreous detachment may also be noted along with whitish, dendrite-like structures and other vascular disorders. When associated with macular alterations, these peripheral lesions of the retina are suggestive of $\mathrm{X}$ linked RS, even if no schisis is found and if the typical 'spokewheel' aspect of the macula has not been recognised. Indeed, these peripheral lesions allow one to rule out other macular degenerations, such as Stargardt's disease which never involves extramacular alterations. ${ }^{1}$

The recognition of peripheral alterations in affected males prompted us to investigate obligate carriers for these particular lesions. In contrast with previous studies, ${ }^{101116}$ we were able to show that a proportion of heterozygous females do express the disease: while no macular alterations were found, a careful investigation of their retinas led to the frequent discovery of peripheral alterations (4/5), similar to those found in affected males. The severity of the symptoms differed among carriers, probably owing to random inactivation of the X chromosome. These features must be taken into account especially since none of them had myopia in our series.

Several linkage studies in RS have been previously reported. ${ }^{49-11}$ 16-20 The disease gene has been already assigned to the distal short arm of the $\mathrm{X}$ chromosome (Xp22.2) between DXS43 and DXS41. In the study by Dahl et al, ${ }^{11}$ the peak lod scores using the DXS43 and DXS41 markers were 4.98 and 4.08 respectively at a recombination fraction $(\theta)$ of zero. Similarly, the study of Alitalo et al ${ }^{10}$ gave maximum lod scores of 13.87 and 9.6 for DXS43 and DXS41 at a recombination fraction of $\hat{\theta}=0.02$ and $\hat{\theta}=0.06$ respectively. Both authors concluded that $D X S 43$ and DXS41 are the two closest informative markers for carrier detection. The present study confirms the close proximity of the RS locus to the distal markers DXS16, DXS207, and DXS43. In addition, our study also confirms that the closest marker centromeric to the disease gene is $D X S 274$, the most likely gene order in the region being Xpter-DXS16-(DXS207$D X S 43)-R S-D X S 274-D X S 41-D X S 164-X$ Cen $^{18}$ In contrast, our study does not support close linkage between the disease gene and the proximal marker DXS41 since five recombination events were observed in 28 informative meioses $(\hat{Z}=1 \cdot 16$ at $\theta=0 \cdot 18$ ). These findings suggest that the genetic distance between $R S$ and the DXS41 marker is greater than previously described. Alternatively, a hot spot for recombination might exist in this region. In keeping with this, a high rate of crossing over has been recently reported between the $D X S 41$ locus and other disease genes of the region, namely those of Duchenne muscular dystrophy ${ }^{21}$ and Coffin-Lowry disease. ${ }^{22}$ These recombination events must be taken into account for risk calculation and genetic counselling and especially for determination of carrier status and prenatal diagnosis.

In conclusion, the present study provides information useful for genetic counselling in cases of $\mathrm{X}$ linked RS. First, we show that, in striking contrast with previous reports, heterozygous carriers frequently express the disease. This feature must be taken into account for risk calculations in affected families. Second, while distal polymorphic markers are closely linked to the disease locus, we believe that the high level of recombination events with the proximal markers represents an important risk of error that must be taken into account in both carrier detection and in prenatal diagnosis.

We should like to thank D Goddé-Jolly, M L Blanck, Y M Ruellan, D Chauvaud, and J Rozembaum for their technical expertise and Gisèle Gal, Nathalie Quénet, and Cécile Glaunec for their help in preparing this manuscript. In France, carrier detection and genetic counselling for RS is supported by the Association Française pour le Dépistage et la Prévention des Handicaps de l'Enfant.

1 Salvanet-Bouccara A, Galaup A. Rétinoschisis juvénile idiopathique des jeunes gens. F Fr Ophtalmol 1983;6:487-93.

2 Forsius H, Eriksson A, Nuutila A, Vainio-Mattila B, Krause U. A genetic study of three rare retinal disorders; dystrophia retinae dysacusis syndrome, $X$ chromosomal retinoschisis and grouped pigments of the retina. Birth Defects 1971;7:83-98.

3 Emery AEH. Estimation of recurrence risks for genetic counselling. In: Methodology in medical genetics. Edinburgh: Churchill Livingstone, 1986:93-113.

4 Wieacker PTF, Wienker B, Dallapiccola K, Bender K, Davies KE, Ropers HH. Linkage relationships between retinoschisis, $\mathrm{Xg}$, and a cloned DNA sequence from the distal short arm of the X chromosome. Hum Genet 1983;64:143-5.

5 Maniatis T. Molecular cloning. A laboratory manual. New York: Cold Spring Harbor Laboratory, 1982:280-1.

6 Southern EM. Detection of specific sequences among DNA fragments separated by gel electrophoresis. F Mol Biol 1975;98: 503-17.

7 Rigby PWJ, Dieckmann $M$, Rhodes C, Berg P. Labelling deoxyribonucleic acid to high specific activity in vitro by nick translation with DNA polymerase 1. F Mol Biol 1977;113: 237-51.

8 Lathrop GM, Lalouel $M$. Easy calculation of lod scores and genetic risks on small computers. Am F Hum Genet 1984;36: 460-5.

9 Alitalo T, Karna J, Forsius H, de la Chapelle A. X-linked retinoschisis is closely linked to DXS41 and DXS16 but not DXS85. Clin Genet 1987;32:192-5.

10 Alitalo $\mathrm{T}$, Forsius $\mathrm{H}$, Karna J, et al. Linkage relationships and gene order around the locus for $\mathrm{X}$-linked retinoschisis. Am $\mathcal{J}$ Hum Genet 1988;43:476-83.

11 Dahl N, Goonewerdena P, Chotai J, Anvret M, Pettersson U. DNA linkage analysis of X-linked retinoschisis. Hum Genet 1988;78:228-32.

12 Keunen JEE, Hoppenbrowers RWJN. A case of sex-linked juvenile retinoschisis with peripheral vascular anomalies. Ophthalmologica 1985;191:146-9.

13 Deutman AF. The hereditary dystrophies of the posterior pole of the eye. Assen: Van Gorcum, 1971:48-98. 
14 Balian JV, Falls HF. Congenital vascular veils in the vitreous. Arch Ophthalmol 1960;63:92-101.

15 Tasman W. Diseases of the retina and vitreous. In: Harley RD, ed. Pediatric ophthalmology. 2nd ed. Philadelphia: Saunders, 1983:599-626.

16 Gellert G, Pettersson J, Krawczak M, Zoll B. Linkage relationship between retinoschisis and four marker loci. Hum Genet 1988;79:382-4.

17 Gal A, Wienker TF, Davies KE, et al. Further linkage studies between retinoschisis and cloned DNA sequences from the distal Xp. HGM8. Cytogenet Cell Genet 1985;40:634.

18 Alitalo T, Forsius H, Karna J, Eriksson AW, Kruse TA, de la Chapelle A. Additional linkage data and gene order around the locus for X-linked retinoschisis. HGM10. Cytogenet Cell Genet 1989;51:950.

19 Dahl N, Pettersson U. Use of linked DNA probes for carrier detection and diagnosis of X-linked juvenile retinoschisis. Arch Ophthalmol 1988;106:1414-6.

20 Sieving P, Bingham E, Roth M, et al. Linkage analysis of juvenile $\mathrm{X}$-linked retinoschisis using four DNA markers. Am $\mathcal{f} \mathrm{Hum}$ Genet 1989;45:161A.

21 Jeanpierre M, Recan D, Kaplan J, Frézal J, Kaplan JC. Genetic analysis of the DMD locus in a large sample of families with DMD or BMD. HGM9. Cytogenet Cell Genet 1987;46:633.

22 Hanauer A, Alembik Y, Gilgenkrantz S, et al. Probable localization of the Coffin-Lowry locus in Xp22.2-p22.1 by multipoint linkage analysis. Am F Med Genet 1988;30:523-30. 